\title{
Effect of Waiting Time on Concentration of Chemical Markers measured on Laboratory Ageing Samples
}

\author{
S. Y. Matharage ${ }^{1}$, Q. Liu ${ }^{1}$, Z.D. Wang ${ }^{1}$, G. Wilson ${ }^{2}$, Y.H. Kim ${ }^{3}$ and R. Martin ${ }^{4}$ \\ ${ }^{1}$ The University of Manchester, Manchester, M13 9PL, United Kingdom \\ ${ }^{2}$ National Grid, Warwick, CV34 6DA, United Kingdom \\ ${ }^{3}$ HYOSUNG Corporation, Anyang, 74 Simin-daero, Republic of Korea \\ ${ }^{4}$ M\&I Materials, Manchester, M32 0ZD, United Kingdom
}

\begin{abstract}
Laboratory scale thermal ageing experiments have been used not only to study the degradation of the insulation materials but also to understand the variation of chemical markers in liquid during the ageing process. However, trends obtained from different experiments often disagree with each other due to experimental variations such as material type, material ratio and ageing temperature. In addition to these wellknown factors, there are lesser- known factors such as the duration for which samples are left at room temperature after an ageing experiment, which could affect the concentration of chemical markers in liquid. It is known that temperature could affect the partitioning of chemical markers among the liquid, solid and gas phase. Hence the concentration of certain chemicalmarkers in liquid could vary depending on the duration for which samples are left at room temperature prior to the sampling of oil for the measurements. This paper investigates the effect of this sampling period on the variation of chemical markers including water, methanol and ethanol in liquid after a laboratory scale ageing experiment conducted at $150{ }^{\circ} \mathrm{C}$. Results showed that the concentration of the investigated chemical markers in liquid decrease continuously when the sample is left at room temperature, with water having the highest reduction followed by methanol and ethanol.
\end{abstract}

\section{INTRODUCTION}

Power transformers require monitoring and management to obtain their optimal performance and maximum service life without unplanned outages or failures. Apart from being an insulation and a heat transfer cooling medium the liquid insulation in transformers support management of these assets by allowing the user to monitor the condition through the presence of gases and other chemical-markers which enable the condition of the paper insulation to be monitored. Paper condition is otherwise difficult to establish as it cannot generally be accessed directly for measurements such as tensile strength and degree of polymerization during the service life of a transformer. Water, 2-furfural (2-FAL), carbon oxide gases ( $\mathrm{CO}$ and $\mathrm{CO} 2)$, methanol, ethanol and low molecular weight acids are such chemical markers in oil, all of which are related to the ageing of paper insulation [1, 2]. Laboratory ageing experiments conducted at high temperatures are used to understand the variation of these chemical markers measured in liquid during the ageing and to develop models to predict ageing of paper insulation. However, many models often do not agree with each other due to differences in the experiments such as material types, material ratios, ageing conditions and ageing temperature [3, 4]. In addition to these well-known and controlled parameters, there are other less-controlled parameters such as the time period for which a sample is left at room temperature at the end of an ageing experiment before sampling oil to measure chemical markers; indeed, this waiting time could also affect the relationship between paper ageing and concentration of chemical markers in liquid due to the temperature dependent dynamics in the partitioning of these indicators during the sample cooling period.

Partitioning of chemical markers between oil and paper is a process that has been studied to support interpretation of measurements obtained from transformers-in-service [5, 6]. These studies have identified temperature as one of the main factors which affects the partitioning of chemical markers within the transformer insulation system.

Water content in oil is measured mainly due to its effect on the dielectric properties. In addition, water content in oil is used with attempt to reflect the water content in paper using equilibrium curves as water acts as a catalyst for paper ageing [7]. Partitioning of water between liquid and solid insulation is highly sensitive to temperature [6]. Furthermore, additional factors such as the ageing condition of oil and paper would also affect the solubility and hence the partitioning between them [8].

It has been proposed to use methanol to indicate the early stage of paper ageing; methanol has also been reported to be a better ageing indicator than 2-FAL for insulation systems with thermally upgraded Kraft paper [9]. Experiments have shown that the partitioning of methanol depends on temperature [6] and oil type [10].

Ethanol, which can be measured together with methanol, has been proposed as an indicator to indicate abnormal paper ageing that occurs at very high temperatures [9]. Experiments have shown that partitioning of ethanol is also temperature dependent but the effect is less pronounced than those of water and methanol [6].

2-FAL is another well-known chemical marker which has been used as a paper ageing indicator for more than three decades [4]. Investigations have shown that the effect of temperature on the partitioning of 2-FAL is considerably lower than that of water or the low molecular weight alcohols, 
i.e. methanol and ethanol [6]. However, it has shown that other factors such as the water content in paper or the ageing of paper insulation could also affect the partitioning of 2-FAL between liquid and solid insulations [5].

Typically, laboratory ageing experiments are conducted at temperatures above $100{ }^{\circ} \mathrm{C}$ to increase the ageing rate and shorten the ageing duration. Once designed ageing period is reached, the aged samples are cooled down at room temperature for certain duration before sampling oil and paper to measure various chemical and physical properties. During this period the sample first undergoes a rapid temperature decrease and stays at room temperature, causing chemical markers to continuously redistribute within the solid, liquid and gas phases of the test cell. Depending on the speed of this process and the amount of migration, the concentration of the chemical markers in each phase will vary with the cooling duration. Therefore, this redistribution needs to be taken into consideration when interpreting the results of any ageing experiment. This paper investigates the effect of waiting time period on the partitioning of chemical markers, with the focus on polar chemical makers such as water, methanol and ethanol.

\section{Experimental Description}

A laboratory ageing experiment was conducted with inhibited mineral oil (NYTRO 10XN from Nynas), thermally upgraded Kraft paper, non-thermally upgraded pressboard, copper and core steel materials to generate chemical markers in the test cell. Table I shows the amount of each material used for the ageing experiment.

TABLE I

MATERIALS USED FOR THE AGEING EXPERIMENT
\begin{tabular}{|l|l|}
\hline Material & Amount \\
\hline Thermally upgraded Kraft paper & $102 \mathrm{~cm}^{3}$ \\
\hline Non-thermally upgraded pressboard & $10.6 \mathrm{~cm}^{3}$ \\
\hline Inhibited mineral oil & $1800 \mathrm{~cm}^{3}$ \\
\hline Copper sheet & $95 \mathrm{~cm}^{2}$ \\
\hline Core steel sheet & $95 \mathrm{~cm}^{2}$ \\
\hline
\end{tabular}

Paper and pressboard samples were first dried at $105{ }^{\circ} \mathrm{C}$ under vacuum of less than $500 \mathrm{~Pa}$ for 72 hours. Next the temperature of the vacuum oven was reduced to $60{ }^{\circ} \mathrm{C}$ and oil was added into the chamber under vacuum. Samples were left inside the vacuum oven for 48 hours to allow the impregnation of paper and pressboard. The oil impregnated paper and pressboard had water content less than $0.5 \%(\mathrm{w} / \mathrm{w})$. Finally, the test samples were prepared by mixing oil, oil-impregnated paper, pressboard and other materials in a 2-litre stainless-steel cell. Fig. 1 shows a sketch of the test cell. Test cell consists of a pressure-relief valve set at $68.9 \mathrm{kPa}(10 \mathrm{psi})$ and two pipes; one connected to the headspace of the cell and the other connected into the oil. The two pipes were used to purge the cell with nitrogen and to sample oil at the end of the experiment without opening the cell. Prior to the ageing experiment test cell was purged with nitrogen and the initial pressure was set at $13.8 \mathrm{kPa}(2 \mathrm{psi})$. Two test cells prepared according to the above procedure were aged at $150{ }^{\circ} \mathrm{C}$ for up to 138 days.

At the end of the experiment, cells were taken out of the oven and $30 \mathrm{ml}$ of oil was sampled immediately into glass syringes from both cells before leaving them at room temperature for 336 hours (14 days). During this period oil was sampled intermittently from one cell (Cell No. 1) and at the end of 336 hours, oil was sampled from both cells. Oil was sampled from the tubing connected into the oil while pressurizing the headspace with nitrogen through the tubing connected to the headspace. It was noted that the oil temperature decreased to room temperature within the first 24 hours of the sampling period.

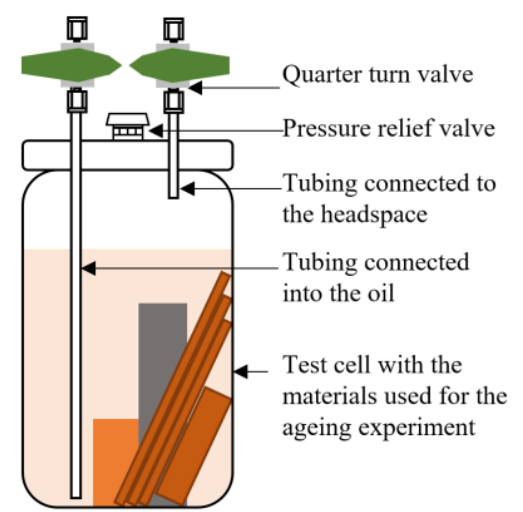

Fig. 1. Sketch of the test cell used for the ageing experiment

Water, methanol and ethanol concentrations were measured in all the oil samples obtained from the test cells. At the end of the 336-hour waiting time period, both test cells were opened and additional measurement of acidity in oil and the degree of polymerization (DP) of the paper were conducted to compare the ageing condition of the cells. Table II shows the standards / procedures used to measure the parameters of oil and paper insulation. Each chemical parameter was measured twice and the average is plotted with the error bars showing high and low values.

TABLE II

PARAMETERS MEASURED AND THE MEASUREMENT TECHNIQUE

\begin{tabular}{|l|l|}
\hline Measurement & Standard / procedure \\
\hline Water content & Evaporative stripping method according to IEC 60814 \\
\hline $\begin{array}{l}\text { Methanol/ } \\
\text { ethanol content }\end{array}$ & $\begin{array}{l}\text { In-house method using a headspace extractor combined } \\
\text { with a gas chromatography and a mass spectrometry unit }\end{array}$ \\
\hline Acidity in oil & Potentiometric titration according to IEC 62021-1 \\
\hline DP of paper & Viscometric method according to IEC 60450 \\
\hline
\end{tabular}

Table III shows the acidity in oil and the DP of paper measured in both test cells. It can be seen that paper in both cells have aged considerably compared to the oil.

$$
\text { TABLE III }
$$

ACIDITY IN OIL AND DEGREE OF POLYMERISATION OF PAPER

\begin{tabular}{|l|l|l|}
\hline Cell number & Acidity $(\mathrm{mg} \mathrm{KOH} / \mathrm{g})$ & Degree of polymerization \\
\hline Cell 1 & 0.04 & 253 \\
\hline Cell 2 & 0.05 & 310 \\
\hline
\end{tabular}

III. Experimental Results and Discussions

\section{A. Variation of the water content in oil}

Fig. 2 shows the variation of water content in oil over the 336-hour waiting time period. Water content in oil reduces rapidly as the sample cools down. At the end of the 336 hours, water content in oil reduced from $191 \mathrm{ppm}$ to $10.5 \mathrm{ppm}$; a 
reduction of more than $95 \%$, with about $83 \%$ of the reduction occurring in the first 24 hours.

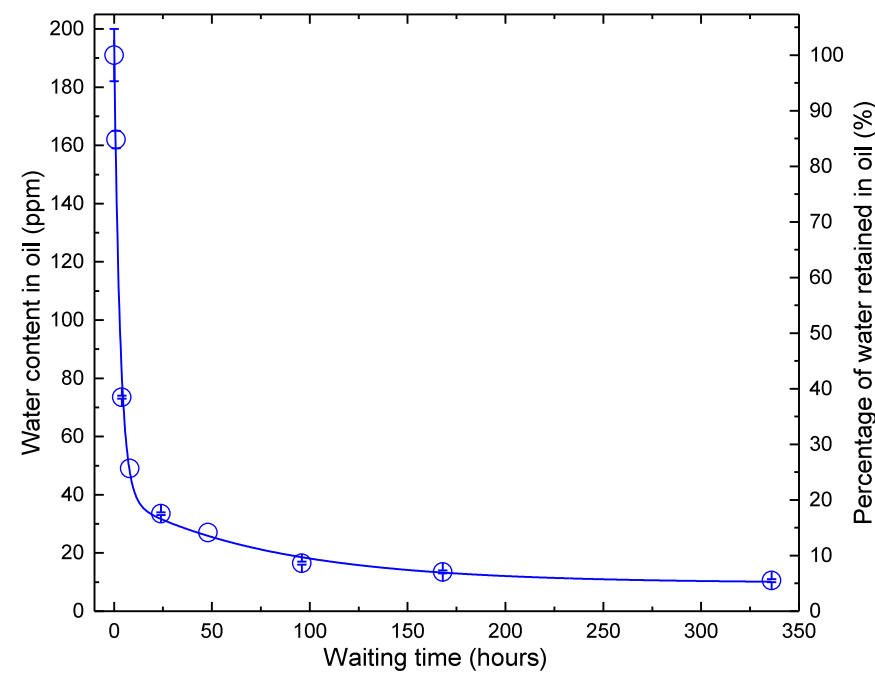

Fig. 2. Variation of the water content in oil during the cooling period

Table IV shows the water content in both cells measured at the beginning and at the end of the waiting period. There is a substantial reduction in the water content in both cells. At the beginning of the waiting time period two cells had water content of $191 \mathrm{ppm}$ and $171.5 \mathrm{ppm}$, respectively. Even though the values appear to be very high, it is still justifiable considering the temperature dependency of the water solubility in mineral oil. Based on the solubility curve given in the mineral oil maintenance guide [11] water solubility of new mineral oil at $150{ }^{\circ} \mathrm{C}$ could be about $2400 \mathrm{ppm}$. Therefore, the relative water saturation level of oil in the two cells will be between $7 \%$ and $8 \%$. However, the water solubility of oil decreases with the decrease in oil temperature resulting in an increase in the relative saturation level, which drives the water into the solid insulation. As shown in Table IV water content in all both cells has reduced by more than $86 \%$ during the waiting period. The results further confirm that water content in oil is highly dependent on the waiting time for sampling after ageing experiment ceased.

TABLE IV

WATER CONTENT IN OIL MEASURED AT THE BEGINNING AND AT THE END OF THE SAMPLING PERIOD

\begin{tabular}{|l|l|l|l|}
\hline Cell & \multicolumn{2}{|c|}{ Water content in oil (ppm) } & Percentage \\
Number & 0 hours & 336 hours & reduction (\%) \\
\hline Cell 1 & 191 & 10.5 & 94.5 \\
\hline Cell 2 & 171.5 & 22.5 & 86.9 \\
\hline
\end{tabular}

\section{B. Variation of methanol content in oil}

Fig. 3 shows the variation of methanol content in oil against the waiting time period for sampling. Methanol content in oil reduced from $3.44 \mathrm{ppm}$ to $0.99 \mathrm{ppm}$ after 336 hours, a more than $70 \%$ reduction from the initial concentration. However, in contrast to water only about $13 \%$ of reduction occurred within the first 24 hours which is lower than the percentage reduction of water during the same period. This indicates that methanol migrates more slowly from oil to paper/pressboard compared with water and takes a longer time to reach equilibrium, which is in line with previous research in [10] which claimed that methanol took more than 50 days to reach equilibrium at room temperature.

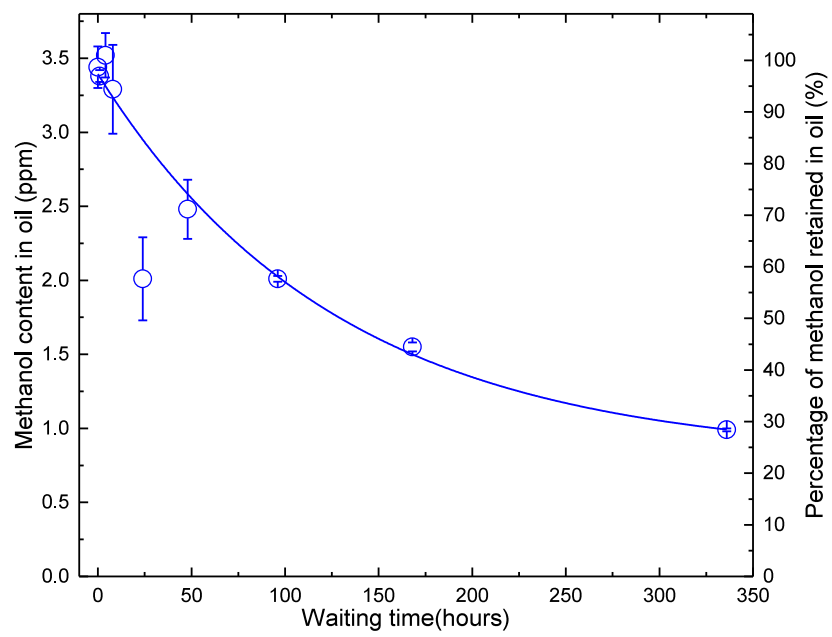

Fig. 3. Variation of the methanol content in oil during the cooling period

Table V compares the methanol content in oil measured of both test cells at the beginning and end of the waiting time period for sampling. After the 336-hour period methanol content in cell 1 and cell 2 has reduced by $71.2 \%$ and $58.7 \%$, respectively. However, it is unlikely for methanol to reach equilibrium even after this period of time, as can be seen in Fig. 3.

TABLE V

METHANOL CONTENT IN OIL MEASURED AT THE BEGINNING AND AT THE END OF SAMPLING PERIOD

\begin{tabular}{|l|l|l|l|}
\hline \multirow{2}{*}{$\begin{array}{l}\text { Cell } \\
\text { Number }\end{array}$} & $\begin{array}{l}\text { Methanol content in oil } \\
(\mathrm{ppm})\end{array}$ & $\begin{array}{l}\text { Percentage } \\
\text { reduction (\%) }\end{array}$ \\
\cline { 2 - 3 } & 0 hours & 336 hours & \\
\hline Cell 1 & 3.44 & 0.99 & 71.2 \\
\hline Cell 2 & 2.76 & 1.14 & 58.7 \\
\hline
\end{tabular}

\section{Variation of ethanol content in oil}

Fig. 4 shows the variation of ethanol content in oil against the waiting time for sampling. During this 336-hour period ethanol content in oil decreased from $0.51 \mathrm{ppm}$ to $0.4 \mathrm{ppm}$ with nearly $20 \%$ reduction, which is much lower compared with the reduction of water and methanol content in oil.

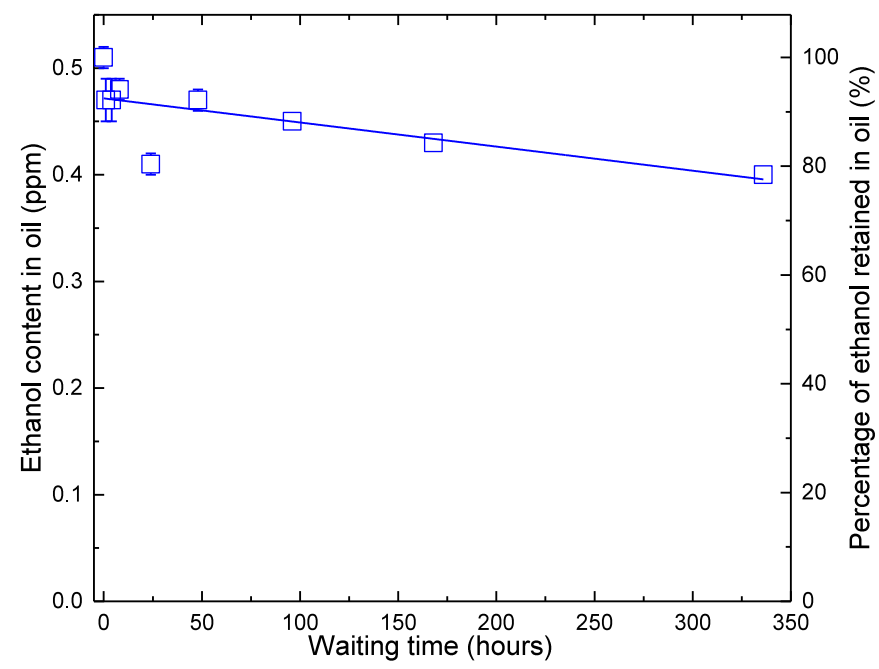

Fig. 4. Variation of ethanol content in oil during the cooling period 
Table VI shows the ethanol content measured in both test cells at the beginning and at the end of the sampling period. It should be noted that these concentrations are much higher than the detection limit of $0.01 \mathrm{ppm}$. Hence, it is confident to say that the ethanol content in both test cells has reduced by about $0.1 \mathrm{ppm}$ resulting in percentage reduction of $21.6 \%$ and $12.8 \%$ respectively. These results confirm that out of the investigated chemical markers partitioning of ethanol has the lowest temperature dependency.

TABLE VI

ETHANOL CONTENT IN OIL MEASURED AT THE BEGINNING AND AT THE END OF SAMPLING PERIOD

\begin{tabular}{|c|c|c|c|}
\hline \multirow{2}{*}{$\begin{array}{l}\text { Cell } \\
\text { Number }\end{array}$} & \multicolumn{2}{|c|}{ Ethanol content in oil (ppm) } & \multirow{2}{*}{$\begin{array}{l}\text { Percentage } \\
\text { reduction }(\%)\end{array}$} \\
\hline & 0 hours & 336 hours & \\
\hline Cell 1 & 0.51 & 0.4 & 21.6 \\
\hline Cell 2 & 0.86 & 0.75 & 12.8 \\
\hline
\end{tabular}

D. Comparison between the percentage reduction of chemical marker concentration in oil during the waiting time for sampling

Fig. 5 shows the average percentage reduction of the chemical marker concentration in oil obtained from both test cells during the 336-hour waiting time period. Water content in oil, with about $91 \%$ reduction, has shown the largest percentage reduction followed by methanol (65\% reduction) and ethanol (17\% reduction).

Even though both samples were prepared and aged under similar conditions, it can be seen that there is still a difference in terms of both absolute and percentage reduction in the chemical marker concentration values between the two cells. Apart from the difference between their initial chemical marker concentrations, variations in the oil to paper ratio during the sampling period could have also contributed to the difference between two test cells. It should be noted that due to oil sampling, oil amount in both cells was less than the initial amount of $1800 \mathrm{ml}$. However due to the continuous oil sampling process, oil in cell 1 was nearly $210 \mathrm{ml}$ lower than that in cell 2, which cause the oil to paper ratio of cell 1 to be different from that of cell 2 .

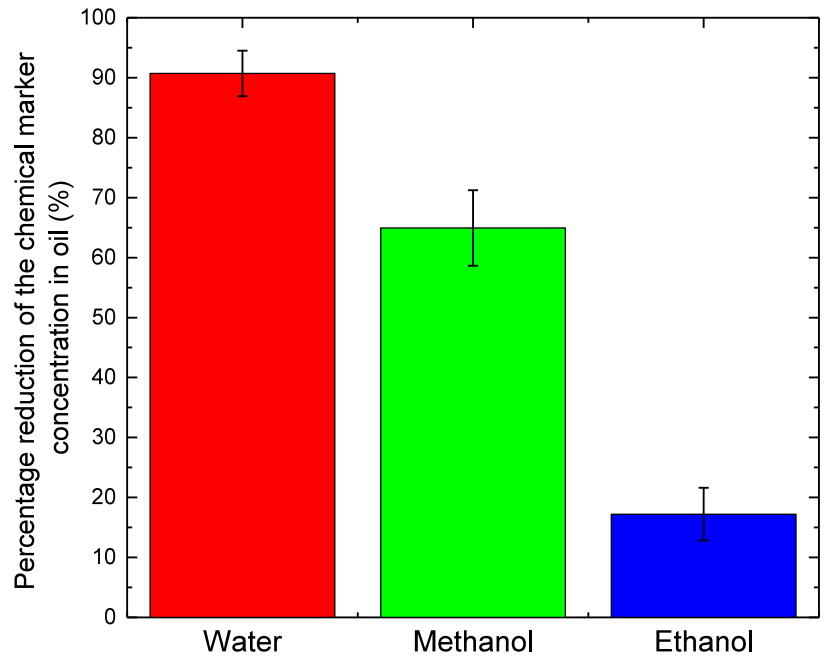

Fig. 5. Percentage reduction of the chemical marker concentration in oil at the end of 336-hour waiting period

\section{Conclusion}

This paper investigates the effect of waiting time for sampling on the concentration of chemical markers in oil measured after laboratory ageing experiments of transformer oil and paper insulations. Test cells with solid and liquid insulation, after ageing experiments at a high temperature; were left at room temperature while the concentrations of the chemical markers were monitored. Results showed that the concentration of chemical markers reduces during this period of waiting time due to their temperature and time dependent partitioning within the insulation system. Water content in oil showed the largest percentage of reduction followed by methanol and ethanol. Results confirm that waiting time for sampling is an important factor which contributes to the variations in the ageing experiment results published in research literature and 'when to sample' needs to be addressed for the laboratory ageing experiments.

\section{ACKNOWLEDGMENT}

The authors would like to express their gratitude to Hyosung Heavy Industries, M\&I Materials and National Grid for the financial and technical contributions to this project at The University of Manchester.

\section{REFERENCES}

[1] N. Azis, Q. Liu, and Z.D. Wang, "Ageing assessment of transformer paper insulation through post mortem analysis," IEEE Transactions on Dielectrics and Electrical Insulation, vol. 21, no. 2, pp. 845-853, 2014.

[2] S. Y. Matharage, Q. Liu, and Z.D. Wang, "Aging assessment of kraft paper insulation through methanol in oil measurement," IEEE Transactions on Dielectrics and Electrical Insulation, vol. 23, no. 3, pp. 1589-1596, 2016

[3] D. Feng, Z.D Wang, and P. Jarman, "Transmission power transformer assessment using furan measurement with the aid of thermal model," in International Conference on Condition Monitoring and Diagnosis (CMD), pp. 521-524, 2012.

[4] L. Cheim, D. Platts, T. Prevost, and S. Xu, "Furan analysis for liquid power transformers," IEEE Electrical Insulation Magazine, vol. 28, no. 2, pp. 8-21, 2012.

[5] Y. Lin, C. Wei, F. Tao, and J. Li, "Aging assessment of oil-paper insulation of power equipment with furfural analysis based on furfural generation and partitioning," IEEE Transactions on Power Delivery, vol. 34, no. 4, pp. 1626-1633, 2019.

[6] J. Jalbert, M. C. Lessard, and M. Ryadi, "Cellulose chemical markers in transformer oil insulation Part 1: Temperature correction factors," IEEE Transactions on Dielectrics and Electrical Insulation, vol. 20, no. 6, pp. 2287-2291, 2013.

[7] T. V. Oommen, "Moisture equilibrium in paper-oil insulation systems," in 6th Electrical/Electronical Insulation Conference (EIC), pp. 162-166, 1983

[8] D. Linhjell, L. E. Lundgaard, and C. M. Selsbak, "Temperaturedependent contamination distribution between oil, paper and pressboard," in IEEE International Conference on Dielectric Liquids, pp. $1-5,2011$.

[9] J. Jalbert, R. Gilbert, P. Tétreault, B. Morin, and D. Lessard-Déziel, "Identification of a chemical indicator of the rupture of 1,4- $\beta$-glycosidic bonds of cellulose in an oil-impregnated insulating paper system," Cellulose, vol. 14, no. 4, pp. 295-309, 2007.

[10] S. Y. Matharage, Q. Liu, Z. D. Wang, G. Wilson, and C. Krause, "Aging assessment of synthetic ester impregnated thermally non-upgraded kraft paper through chemical markers in oil," IEEE Transactions on Dielectrics and Electrical Insulation, vol. 25, no. 2, pp. 507-515, 2018.

[11] IEC 60422: Mineral insulating oils in electrical equipment. Supervision and maintenance guidance, 2013. 